\title{
$\mathrm{LR}=$ INTERNATIONAL JOURNAL OF ACADEMIC \\ HUMAN RESOURCE
MEAAGEENT CADAEMIC
RESEARCH SOCIETY

\section{The Controversial Association between "The Family Effect" and Corporate Performance: Analysis of Longitudinal Data}

Francesco Campanella, Luana Serino, Anna Crisci

To Link this Article: http://dx.doi.org/10.6007/IJARAFMS/v11-i2/9999

DOI:10.6007/IJARAFMS /v11-i2/9999

Received: 04 March 2021, Revised: 10 April 2021, Accepted: 24 April 2021

Published Online: 19 May 2021

In-Text Citation: (Campanella et al., 2021)

To Cite this Article: Campanella, F., Serino, L., \& Crisci, A. (2021). The Controversial Association between "The Family Effect" and Corporate Performance: Analysis of Longitudinal Data. International Journal of Academic Research in Accounting Finance and Management Sciences, 11(2), 90-105.

Copyright: (c) 2021 The Author(s)

Published by Human Resource Management Academic Research Society (www.hrmars.com)

This article is published under the Creative Commons Attribution (CC BY 4.0) license. Anyone may reproduce, distribute, translate and create derivative works of this article (for both commercial and non-commercial purposes), subject to full attribution to the original publication and authors. The full terms of this license may be seen

at: http://creativecommons.org/licences/by/4.0/legalcode

Vol. 11, No. 2, 2021, Pg. 90 - 105

Full Terms \& Conditions of access and use can be found at http://hrmars.com/index.php/pages/detail/publication-ethics 


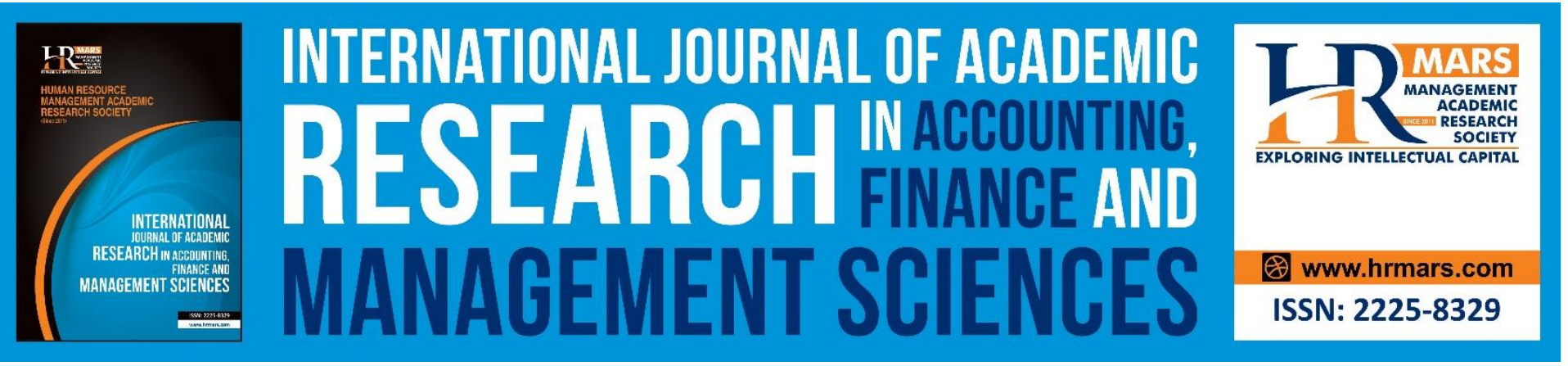

\title{
The Controversial Association between "The Family Effect" and Corporate Performance: Analysis of Longitudinal Data
}

\author{
Francesco Campanella1, Luana Serino ${ }^{1}$, Anna Crisci ${ }^{2}$ \\ 'Department of Economics, University of Campania "Luigi Vanvitelli" Capua, Italy, 2Department of \\ Economic, Management, Institutions, University of Naples Federico II \\ Email: luana.serino@unicampania.it
}

\begin{abstract}
Small firms that are managed or controlled by founding families, hereafter, referred to as family firms, constitute an important source of the economic system in Italy. We found family firms are more likely to outperform non-family firm. After controlling for firm specific variables, we find a positive association between family ownership and firm; while the management by family members seems not to impact on corporate performance. This research demonstrates the correlation between the family firms and the performance depends greatly on the type of family business, as well as the influence that the founding family exercises, through ownership and/or management.
\end{abstract}

Keywords: Governance, Family Firms, Management, Performance

\section{Introduction}

Although conventional economic theory does not differentiate management decisions between family firms and other firms that are owned by diverse shareholders, the relation between family governance and firm' profitability is a critical issue in corporate governance research. A large body of literature shows that family firms are common among public corporations around the world (Anderson and Reeb, 2003; La Porta, López de Silanes \& Shleifer, 1999). However, whether family firms are more or less performing than non-family firms remains to be investigated. In addition, the empirical findings concerning the effect of family ownership upon the performance are discordant. Mixed results found regarding the impact of family ownership on firm performance as well (Morck, Stangeland \& Yeung, 2000; Claessens et al., 2002). For example, using a large sample of U.S. corporations, Holderness and Sheehan (1988) find that family firms have a lower Tobin's $q$ than nonfamily counterparts, while Anderson and Reeb (2003) found the opposite.

For different decades, the family firms have been harshly criticized by academics. Family firms are viewed as conservative and suffering from a strong form nepotism (Schulze,Lubatkin \& Dino, 2003) determining the dearth of professional management (Chandler, 1990) and competences (Schulze et al., 2001). This typical portrayal of a family firm suggests that these types of economic organizations 
INTERNATIONAL JOURNAL OF ACADEMIC RESEARCH IN ACCOUNTING, FINANCE AND

MANAGEMENT SCIENCES

Vol. 11, No. 2, 2021, E-ISSN: 2225-8329 @ 2021 HRMARS

may be less performing than other non-family firms (Allen \& Panian, 1982; Gomez-Mejia, LarrazaKintana \& Makri 2003; Perez-Gonzalez, 2006).

Despite the criticisms, several studies found that the family businesses outperform along a great many dimensions than non-family businesses (Allouche \& Amann, 2000; Anderson \& Reeb, 2003). Indeed, prior research (Berle \& Means, 1932; Jensen \& Meckling,1976) stated that firms which have concentrated ownership and/or voting rights that may enhance performance. In addition to ownership concentration, academic researchers have widely explored the relation between the family ownership and the firm performance. Morck, Stangeland and Yeung (2000), in a study on Canadian firms, argue that family businesses have a negative impact on firm performance. This is due to the fact the family firms are conservative and tend to invest in low risk and consequently low returns projects, with detrimental effects of corporate value. On other side, there are studies (e.g. Anderson \& Reeb, 2003) that argued that family control may lead to a reduction of the free-riding risk by managers and to reduce the agency problems between owners and managers (Maury \& Pajuste 2005) for the benefit of firm value.

These findings raise an important question concerning the link between family governance and performance. There a positive family effect on firm value in terms of performance? The answer to this research question may help us understand the family effect on corporate performance in firms located in Italy.

The objective of this study is to empirically investigate the competitiveness of family versus nonfamily firms. Indeed, in this study we specifically test the hypothesis that family ownership or control leads to better economic performance and thus profitability. In addition, if family business owners also participate in management decisions, they may enhance employee productivity and overall firm performance

So, Italy is uniquely suited to this research because the presence of family-owned firms is Italy is pervasive; indeed, a large portion of Italian companies, especially smaller ones, is run as a family business, or has some key family shareholders who have a great influence on the company affairs (Fabbrini \& Micucci, 2004; Lotti \& Santarelli, 2005). In Italy it is estimated that there are around 784,000 companies - equal to over $85 \%$ of the company total and they account for about $70 \%$ in terms of employment (EY - Family Business Yearbook 2017).

The vast majority of research on family businesses has been conducted with reference to listed larger companies because they are more likely to make public information. To our knowledge, no study has examined the relationship between small-medium family firms and performance in Italy.

On these bases, the aim of this study is to provide new evidence on the scarcely researched relationship between family governance and performance in family firms, focusing on the special features of these firms and distinguishing the different kind of family businesses both on the management side and on the ownership side.

Hence, our work contributes to the extant literature, filling an empirical lack, by establishing a relationship between family ownership and firm' performance. We intend to investigate two questions: first, if the family firms are more performing than to widely held firms. Second, we investigate whether corporate performance is influenced by the type of family firm.

In addition, our study demonstrates the importance of the founding family in the corporate ownership since it could affect the profitability of the firms in Italy. However, our paper highlights the impact of nepotism on firm financial outcomes, suggesting how in the family businesses the practice of nepotism may negatively affect the family firm success. 
INTERNATIONAL JOURNAL OF ACADEMIC RESEARCH IN ACCOUNTING, FINANCE AND MANAGEMENT SCIENCES

Vol. 11, No. 2, 2021, E-ISSN: 2225-8329 @ 2021 HRMARS

The remainder of this essay is structured as follows. In Section 2, we review the related literature on relationship between family governance and performance and present research hypothesis. In Section 3, we then discuss the data and research methodology. The results are presented in Section 4. While, Section 5 summarizes and concludes our research findings.

\section{Literature Review}

\section{Definition of family firms}

Family business researchers have long sought to understand the deep-rooted impact of family involvement in ownership and management on firm performance (Azila-Gbettor et al., 2018). Owners and managers represent the main arbiters of governance mechanisms needed to make decisions about the patterns of incentives, resource allocation, and conflict resolution in a firm (Carney, 2005). Considering their importance, in this research we discuss some of the possible configurations of family governance employed to direct and influence firm competitiveness and performance.

The dualism of family firms versus their nonfamily counterparts can be viewed from two perspectives-ownership and management.

From the perspective of ownership, the uniqueness of family firms is that family members hold a substantial amount of the firm's assets.

From the management perspective, one common characteristic of family firms is that family members serve as the firm's CEOs or fill other top management positions.

About the definition of family business, the literature is wide-ranging, and it is difficult to find consensus on a single, shared definition of a family firm. Probably, the lack of consensus relating to a universally respected family firm definition may be the cause of so different and mixed empirical results about the relationship between the family ownership and performance (Campanella et al., 2020). Indeed, whether different is the family firm definition used, different is in how such businesses perform. Table 1 shows the main definitions of family firms that have been used in academic studies. Table 1: Definition of family business the literature_here

Source: Authors 'elaboration

According to previous studies (Melis, 1999 and 2000; Molteni, 1997), Italian firm are under the relevant influence of large blockholders. While in the US economy, top managers are the most powerful insiders, in Italy, just like Japan, large blockholders play such role (Barca \& Becht, 2001). In accordance with Melis (2000) the Italian governance system can be viewed as an economic system of 'weak managers, strong blockholders and unprotected minority shareholders' (p. 354). So, many founding families in Italy do not exert influence over the firm as a shareholder. Then, the issue of non-voting shares is largely diffused among the Italian businesses (Barca, 1993; Melis, 2000) However, in terms of management, there are few outside managers and in the typical Italian family business the manager and owner are the same, especially in smaller ones. In this entrepreneurial context, by a family business we mean the firm in which founding family is the largest shareholder firm and/or the founder or his descendant is a president or chairman (Dlugosz et al., 2006; Zhang et al., 2020; Saito, 2008). 
INTERNATIONAL JOURNAL OF ACADEMIC RESEARCH IN ACCOUNTING, FINANCE AND

MANAGEMENT SCIENCES

Vol. 11, No. 2, 2021, E-ISSN: 2225-8329 @ 2021 HRMARS

The influence of family governance on corporate performance

In recent years, research on family firms has blossomed but much of the empirical analysis has been devoted to relatively large firms in the U.S. economy (Anderson \& Reeb, 2003; Pérez-González, 2006; Villalonga \& Amit, 2006). However, empirical studies of relationship between family ownership and firm performance have produced mixed results, and, as Anderson and Reeb (2003) conclude, this link remains an open question. Some studies (Demsetz \& Lehn, 1985; Coles, Lemmon \& Meschke, 2012) argued that the correlation between corporate ownership and performance is difficult to estimate due to endogeneity, that it is unobservable to the econometrician. These studies found no evidence of a statistically significant relationship between ownership and firm performance, consistent with the view that they are endogenous.

However, the literature concerning the family ownership and firm performance is voluminous and still growing. According to the incentive effect (Jensen \& Meckling, 1976), a positive relationship exists between management, ownership and firm performance. Indeed, when managerial shareholding increases, the economic interests of managers and those of shareholders are aligned $s$ and so managers are more likely to pursue higher firm value. This situation leads to obvious benefits both for managers and the other shareholders. Stein (1989) argued that family-owned firms are less myopic and are more likely to make better investment decisions. This better decision making is due to the entrepreneur's better knowledge of the company that, in a long-term period, implies a higher degree of performance (Daspit et al., 2018; James, 1999).

Several studies found that Tobin's q of family firms is greater than that of other corporations, showing the higher performance of family owned firms than non-family. Some prior research (Anderson and Reeb 2003, 2004, McConaughy, Walker, Henderson \& Mishra 1998; Villalonga and Amit,2006) report that the Tobin's q of family firms is greater than that of other corporations. However, evidence suggests a discount factor associated with the use of instruments that ensure a disproportionate voting rights (Villalonga \& Amit, 2006a). So, higher performance within family firms is less prevalent within firms that have disproportionate voting power (Miller,Le Breton-Miller \& Scholnick, 2008). Consistent with incentive effect in agency theory (Jensen, 1986), Wu and Huang (2008) found that directors' family shareholdings positively impact on firm performance. This result means that there are pressures to maximize corporate performance upon directors exist when their family 'economic future is at stake (Serino et al., 2020; Dyer, 2018).

In contrast with the studies that stated a positive relationship between family involvement and performance, other research argued that the family ownership tends to be associated with lower productivity and to be opposed to firm value maximization (Barth, Gulbrandsen \& Schøne, 2005; Bertrand \& Schoar, 2006; Gomez-Mejia et al., 2001; Maury, 2006; van der Zee, 2013). The study done by Claessens et al. (2002) show that in Southeast Asian countries, family firms underperform relative to nonfamily firms. According to Cucculelli and Micucci (2008), that family firms are not necessarily more profitable than others. Indeed, the inherited management negatively impacts on the corporate performance, and this decrease in performance is concentrated among the businesses that outperform sectoral average profitability before succession. Moreover, the reduction in profitability is larger in more competitive sectors, where the skills and managerial competences of the founder is more valuable (Campanella et al., 2020).

Some studies found that only some types of family firms outperform non-family firms. Villalonga and Amit (2006) found that family ownership improves corporate performance only when the founder serves as CEO of the company. Saito (2008) showed that the family firms are better performing when 
INTERNATIONAL JOURNAL OF ACADEMIC RESEARCH IN ACCOUNTING, FINANCE AND MANAGEMENT SCIENCES

Vol. 11, No. 2, 2021, E-ISSN: 2225-8329 ๔ 2021 HRMARS

the senior manager is not from the founding family and the founding family shareholders plays a significant role in monitoring directors. Several papers stated the lower performance of family firms is correlated with the involvement in the firm' management of members of family firms. These members often have not managerial skills and competences adequate to manage a firm. Thus, PerezGonzalez (2006) and Bennedsen, Nielsen, Pérez-González, \& Wolfenzon (2007) show that nepotism within a family firm lowers firm profitability. Perez-Gozalez (2006) found that the family successors are more likely to be promoted to the CEO without taking into consideration talent, skills and merit. Bennedsen et al. (2007) showed that the firms, when family manager announces his/her resignation, undergo large declines in operating returns on assets. Consistent with wasteful nepotism, Bertrand, Johnson, Samphantharak and Schoa (2008) found that a wider involvement of family members in family firms hurts corporate performance.

According to the literature, we would to investigate the following hypothesis:

Hypothesis. The family governance is significantly correlated with the corporate performance.

In order to investigate in depth this research hypothesis, we consider different firm specific variables that allow us to clarify the link between the influence of the founding family and the firm performance.

\section{Methodology}

Sample and Family Firm Data description

This study consists of a sample of 295 Italian small-medium firms with four years of observations from 2013 to 2016, resulting in a sample of 1180 company year observations. Our sample includes only small and medium enterprises, selected in accordance with the EU definitions (European Commission, 2003). Thus, SMEs category includes all the businesses which have less than 250 employees. Then, the number of the employee is the cut off used for SMEs definition.

However, data are lacking for most firms in the small-business sector. Except for company financial measures, most data can only be gathered by direct interviews. This situation has led to academics to focus their own studies to larger companies. In this paper, a dataset has been constructed by matching two sources: a survey dataset collected directly from the companies using questionnairebased phone interviews, and data consisting of company accounts obtained from Thomson Reuters. The survey has been restricted to a unique set of small-sized and medium-sized family businesses in the Italian manufacturing industry. The sample period is 2013-2016. This means, repeated observations (four years) on the same set of cross-section units (295 firms), the total observations are $N=1180$.

To investigate in depth the link between family governance and performance, we collect family ownership and management data for all the sample firm-years. In order to classify different types of family firms, we relied on two assumptions of family ownership and family management. Family ownership is defined as the percentage of shares held by the founding family as a group. A firm is family-managed when there are relationships between senior managers and founding families.In accordance with Saito (2008), we classify the family firm into three type family firms: Management\&Ownership family firms (M\&O), Ownership family firms (O), Management family firms. Firstly, the family firm (M\&O) is a firm where the senior manager (president or chairman) is either the founder or his descendant and the founding family is the largest shareholder. In this type of firm, the founding family has influence through both management and ownership. Second, in the Ownership family firms, the founding family has influence only through ownership (Shleifer and 
INTERNATIONAL JOURNAL OF ACADEMIC RESEARCH IN ACCOUNTING, FINANCE AND

MANAGEMENT SCIENCES

Vol. 11, No. 2, 2021, E-ISSN: 2225-8329 @ 2021 HRMARS

Vishny, 1986). In fact, in this type of family firms, the founding family is the largest shareholder, but the senior manager is not a family member. Third, in the management family firm (M) there is a largest shareholder who is not from the founding family. So, the senior manager is from the founding family, constrained by other large shareholders, and the founding family is not the largest shareholder.

The following Table 2 shows the characteristics of the sample employed in our research.

Table 2: Characteristics of research sample_here

We examine the research questions by applying ROA ratio as performance measure and as dependent variable in a Panel data, along with independent variables represent family ownership. In this way, we may investigate the relationship between family firms and firm performance. In corporate governance research, there are different ways to measuring firm performance with little agreement on the most optimal one. However, the main types of performance indicators employed are financial statement ratios. We chose ROA index as proxy of performance in accordance with previous analysis carried out by other authors in this field. In addition, the accounting index ROA is widely regarded as the most useful measure to test firm performance (Abdel Shahid, 2003; Long \& Ravenscraft, 1984, Reese and Cool, 1978; Zeitun \& Tian, 2007).

Following Barber and Lyon (1996), we calculate ROA as ratio (\%) of operating income before tax and interests to market value of assets.

The independent variables are various family firm variables. In particular, our independent variables are the followings:

Family firms: this is a dummy variable, which sets at 1 if the firms if the senior manager is a founding family member and/or the founding family is the largest shareholder in the company;

Ownership: this variable indicates the family ownership expressed as the percentage (\%) of shares owned by the founding family;

$O$ family firms: this is a binary dummy that assumes the value of 1 if founding family is the largest shareholder of the firm, but senior manager is not member of the founding family; 0 otherwise;

$M$ family firms: this is a binary dummy that sets at 1 if founder or his descendant is a president or chairman, but founding family is not the largest shareholder of the firm.

$M \& O$ family firms: this is a variable dummy that assumes the value of 1 if founder or his descendant is a president or chairman and founding family is the largest shareholder of the firm; 0 otherwise

\section{The panel data}

We often have data where variables have been measured for the same subjects (or countries, or companies, or whatever) at multiple points in time. These are typically referred to as Panel Data or as Cross-Sectional Time Series Data. With panel data you can include variables at different levels of analysis (i.e. students, schools, districts, states) suitable for multilevel or hierarchical modeling. Moreover, Panel data facilitates the estimation of causal effects because it can be used to control for unobserved variables.

Panel data possess several advantages: a) they allow to identify the effects that are not identified in the cross-section data. (Ben-Porath,1973); b) while the cross-section allows you to estimate what proportion of the population is unemployed in a unit of time, the panel data show how this share varies over time; c) they allow you to control the effect of individual heterogeneity: i.e variables constant over time (individual heterogeneity) not observed (for which no data are available). (Baltagi 
INTERNATIONAL JOURNAL OF ACADEMIC RESEARCH IN ACCOUNTING, FINANCE AND

MANAGEMENT SCIENCES

Vol. 11, No. 2, 2021, E-ISSN: 2225-8329 @ 2021 HRMARS

and Levin, 1992); d) the panel data permits empirical tests of a wide range of hypotheses; e) The panel data contain more information, giving more efficient estimates.

\section{Fixed and Random Effects}

The fixed effects (FE) explore the relationship between predictor and outcome variables within an entity (persons, teams, company, etc.). Each entity has its own individual characteristics that may or may not influence the predictor variables. Each entity is different, therefore the entity's error term and the constant (which captures individual characteristics) should not be correlated with the others (Stock and Watson, 2012).

The fixed effect model is:

$\boldsymbol{y}_{i t}=\boldsymbol{\beta}^{\prime} \boldsymbol{x}_{i t}+\alpha_{i}+\boldsymbol{\varepsilon}_{i t}$

where

$\alpha_{i}(\mathrm{i}=1 \ldots \mathrm{n})$ is the unknown intercept for each entity ( $\mathrm{n}$ entity-specific intercepts).

$\boldsymbol{y}_{i t}$ is the vector of dependent variables where $\mathrm{i}=$ entity and $\mathrm{t}=$ time.

$\boldsymbol{x}_{i t}$ represent the vector of covariates.

$\boldsymbol{\varepsilon}_{i t}$ is the vector of error terms.

In the random effects the variation across entities is assumed to be random and uncorrelated with the predictor or independent variables included in the model. The essential distinction between fixed and random effects is whether the unobserved individual effect integrate elements that are correlated with the regressors in the model, not whether these effects are "stochastic or not" (Green,

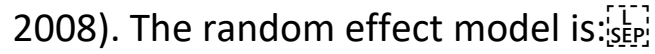

$$
\boldsymbol{y}_{i t}=\boldsymbol{\beta}^{\prime} \boldsymbol{x}_{i t}+\boldsymbol{v}_{i t}
$$

where $\boldsymbol{v}_{i t}=\alpha_{i}+\boldsymbol{\varepsilon}_{i t}$ is the error of the random effect model.

Random effects assume that the error term is not correlated with the predictors which allows for time-invariant variables to play a role as explanatory variables.

The usually accepted way of choosing between fixed and random effects is Hausman $\mathrm{H}$-test (Hausman, 1978). Statistically, fixed effects are always a reasonable thing to do with panel data (they always give consistent results) but they may not be the most efficient model to run. Random effects will give you better $p$-values as they are a more efficient estimator, so you should run random effects if it is statistically justifiable to do so.

Then, under the null hypothesis, the random effects are correctly specified, so both the fixed and random effects model are consistent, while under the alternative hypothesis, the random effects are correlated with the regressors, so the random effects model loses its consistency.

Thus, the Hausman test:

$H_{0}$ : The random effects model is appropriate. The preferred estimator is RE

$H_{1}$ : The fixed effects model is appropriate. The preferred estimator is FE

\section{Empirical Results}

In this work, we consider a panel data in order to analyze the association between family governance and performance. The output of the fixed effects is shown in table 3

Table 3: Fixed effects results_here 
The fixed effects model, in table 3 , shows a significant overall model (p.value $=0.000$ ), with all significant variables, except the variables $M$ family firm and $M \& O$ family firm.

Moreover, we test if time fixed effects are needed by testparm. It is a joint test to see if the dummies for all years are equal to 0 , if they are then no time fixed effects are needed. In our case the p.value is greater than 0.05 , so we failed to reject the null that the coefficients for all years are jointly equal to zero, therefore no time fixed- effects are needed in this case.

The output of the random effects is shown in table 4:

Table 4: GLS Random Effects results_here

In the random effects model (table 4) we have all variables statistically significant, except the variable $\mathrm{M}$ family firm. To see if there are random effects we have carried out the Breusch-Pagan Lagrange Multiplier (LM) test. The LM test helps you decide between a random effects regression and a simple OLS regression. The null hypothesis in the LM test is that variances across entities is zero. If the null hypothesis is not rejected, the pooled OLS is preferred; otherwise, the random effect model is better. In our case the p.value $<0.05$, then we reject the null hypothesis and we conclude that there are random effects.

Later, in order to decide between fixed or random effects we can run a Hausman test where the null hypothesis is that the preferred model is random effects vs. the alternative the fixed effects. The Hausman $\mathrm{H}$-test reveals that the fixed effects estimator is more appropriate (p.value $=0.0019$ ). As the matter of fact, under $H_{1}$ the RE is the best (the estimation GLS is BLUE), while, under $H_{0}$, the statistics properties of the estimator GLS of the RE are not met.

The choice of dealing with individual effects as fixed or random enough delicate. The fixed effects should be used to estimate the specific effects of the sample (i.e, an exhaustive sample countries, a sample of companies in a particular industry in which the selected sample is representative of the characteristics of the industry). By contrast, the random effects should be used for random samples and to make inference on the population.

For this reason, with a reference to our case study the choice falls on the random effects model (table 4) as our entity can really be thought of as random draws from a population. Then, from analysis of table 4 only Management variable is not statistically linked to ROA dependent variables. This means that family management in itself does not significantly contribute to improve the corporate profitability. The variable Family positively has a positive effect on the extent of ROA (coeff.=1.787, p.value $=0.003$ ). In accordance with this result, we can say that family firms are more performing than non-family firms. The variable Ownership, representing the family ownership expressed as the percentage (\%) of shares owned by the founding family; has a positive effect on the extent of ROA (coeff.= 0.026, p.value $=0,001$ ). In this sense, we can say that the increase of family ownership is positively correlated with corporate performance. The variable $O$ is statistically linked to the dependent variable (coeff. $=2.498$, p.value $=0,000$ ). This result means the situation in which the founding family is the largest shareholder, but the senior manager is not a founding family member has a positive effect on the corporate performance. The binary dummy $M \& O$ family firms have a positive effect on the extent of performance (coeff $=0.915$ : $p$ value $=0.053$ ). In accordance with this result, we assume that the situation in which the founder or his descendant is a president or chairman of the firm and founding family is the largest shareholder of the firm has a positive effect on the 
INTERNATIONAL JOURNAL OF ACADEMIC RESEARCH IN ACCOUNTING, FINANCE AND

MANAGEMENT SCIENCES

Vol. 11, No. 2, 2021, E-ISSN: 2225-8329 @ 2021 HRMARS

corporate profitability. The discussion and implications of these statistical results take place in the following section.

\section{Discussion and Conclusion}

Overall, the empirical findings reveal that Italian family firm outperform non-family firms.

We found that family firms are more performing than non-family firms because the family variable dummy is positively correlated the selected proxy of performance.

Furthermore, after controlling for specific firm variables, we find a positive association ownership variable and firm performance. Furthermore, the family ownership contributes to enhance the economic value produced within the company. So, the increase of family ownership, expressed as ratio of shares held by founding family as a group to total shares. is positively correlated with corporate performance. This result strengthens the assumption shared among some researchers that family-owned firms are more likely to better perform compared to non-family counterparts.

In order to investigate whether the management of the founding family is positively correlated with the corporate performance, we distinguish three types of family firms. In fact, Management\&Ownership family firms, only Management family firms, and only Ownership family firms are selected. To our research question "There a positive family effect on firm value in terms of performance?", the response is mixed. In fact, the positive effect on firm performance depends on the type of firm.

Our findings reveal that that family ownership contributes to improve the corporate performance only in two cases:

1) when the senior manager is either the founder or his descendant, and the founding family is the largest shareholder; 2) when the founding family is the largest shareholder, but the senior manager is not a founding family member. In other words, the key element to ensure that the family firm is more performing than non-family firm resides in the fact that the founding family is the largest shareholder.

In other words, the family involvement in the management of business does not means a significant improve on the economic outcomes. Hence, our research hypothesis is partially supported.

The potential benefit of founding family holding large ownership stakes is that it provides them with having important financial incentives to reinforce company' performance (Xu, Ong, \& Nee,2017; Leland and Pule,1977). Our empirical findings for family firms in Italy are somewhat surprising. The founding family could affect firm performance in various ways. According to classical agency theory, an advantage of the family firm in which the founding family is the largest shareholder is that it has a lot of equity and it has strong financial incentives to improve firm performance. In this way, the founding family contribute to the firm performance, even if it has influence only through ownership (Shleifer \& Vishny, 1986). On the other side, family firms where the founding family exercises own influence through only management do not significantly correlated with the performance. Several studies (Allen \& Panian, 1982; Bennedsen et al., 2007; Chandler, 1990; Perez-Gonzalez, 2006) show that nepotism within a family firm damages corporate performance. Nepotism may bring conflicts of interest between family members (or between family members and other stakeholders, as well as reputational concerns.

In particular, a wider involvement of family members in family firms hurts firm value in terms of profitability (Bertrand et al., 2008; Gomez-Mejia et al., 2003). 
INTERNATIONAL JOURNAL OF ACADEMIC RESEARCH IN ACCOUNTING, FINANCE AND MANAGEMENT SCIENCES

Vol. 11, No. 2, 2021, E-ISSN: 2225-8329 @ 2021 HRMARS

The main managerial implications of this study are two. First, we found that family ownership improves the firm' performance. Second, the only family management does not contribute to improve the corporate profitability. This research illustrates the importance of distinguishing the different types of family firms. It demonstrates that the correlation between the family firms and the corporate performance depends greatly on the type of family business, as well as the influence that the founding family exercises, through ownership and/or management. Clear specification is critical in examining the relation between the family governance and the corporate performance (Demsetz and Lehn, 1985; Gillan, 2006).

However, our paper is not without limitations. Firstly, the research sample is limited to Italy. So, our findings cannot be generalized to other countries. Secondly, to measure firm performance we use only a performance proxy, that is ROA index. However, even if the accounting measures are widely seen as efficient proxy measures for corporate performance, there are other measures of performance called market performance measures, such as price per share to the earnings per share (P/E) (Abdel Shahid, 2003) and Tobin's Q that is used in many studies (Favero et al.,2006; Miller et al.,2007; Morck, Shleifer \& Vishny, 1988, McConnel \& Serveas, 1990, Zhou, 2001). The accounting measures, even if most used in academic research, can be easily manipulated by changes in accounting policies and make difficult to compare accounting measures across the companies due to different accounting policies.

Further research about the family governance may help us understand their unique contribution to firm performance, by using different accounting ratios and a larger sample.

\section{References}

Allen, M. P., \& Panian, S. K. (1982). Power, performance, and succession in the large corporation. Administrative Science Quarterly, 538-547.

Allouche, J., \& Amann, B. (2000). L'entreprise familiale: un état de l'art. Finance Contrôle Stratégie, 3(1), 33-79.

Anderson, R. C., \& Reeb, D. M. (2003). Founding-family ownership and firm performance: evidence from the S\&P 500. The journal of finance, 58(3), 1301-1328.

Ang, J. S., Cole, R. A., \& Lin, J. W. (2000). Agency costs and ownership structure. the Journal of Finance, 55(1), 81-106.

Azila-Gbettor, E. M., Honyenuga, B. Q., Berent-Braun, M. M., \& Kil, A. (2018). Structural aspects of corporate governance and family firm performance: a systematic review. Journal of Family Business Management.

Baltagi, B. H., and Levin D. (1992). “Cigarette Taxation: Raising Revenue and Reducing Consumption". Structural change and Economics Dynamic 3(2) 321-335.

Barca, F. (1993). Allocazione e riallocazione della proprietà e del controllo delle imprese: ostacoli, intermediari, regole. Banca d'Italia.

Barca, F., \& Becht, M. (2001). Ownership and control: A European perspective.

Barth, E., Gulbrandsen, T., \& Schøne, P. (2005). Family ownership and productivity: The role of ownermanagement. Journal of Corporate Finance, 11, 107-127

Ben-Porath, Y. (1973). "Labor-Force Participation Rates and the Supply of Labor." Journal of Political Economy, 81(3), pp. 697-704. 
INTERNATIONAL JOURNAL OF ACADEMIC RESEARCH IN ACCOUNTING, FINANCE AND

MANAGEMENT SCIENCES

Vol. 11, No. 2, 2021, E-ISSN: 2225-8329 @ 2021 HRMARS

Bennedsen, M., Nielsen, K. M., Pérez-González, F., \& Wolfenzon, D. (2007). Inside the family firm: The role of families in succession decisions and performance. The Quarterly Journal of Economics, 122(2), 647-691.

Berle, A. A., and Means, G. C. (1932). The Modern Corporation and Property. New York: Harcourt.

Bertrand, M., Johnson, S., Samphantharak, K., \& Schoar, A. (2008). Mixing family with business: A study of Thai business groups and the families behind them. Journal of financial Economics, 88(3), 466-498.

Bertrand, M., \& Schoar, A. (2006). The role of family in family firms. Journal of economic perspectives, 20(2), 73-96.

Campanella, F., Gangi, F., Mustilli, M., \& Serino, L. (2020). The effects of the credit selection criteria on non-performing loans. Meditari Accountancy Research.

Campanella, F., Serino, L., Mustilli, M., Crisci, A., \& D'Ambra, A. (2020). The evaluation of performance in the European public e-health services sector by Generalized Estimating Equations. SocioEconomic Planning Sciences, 100813. Carney, M. (2005). Corporate governance and competitive advantage in family-controlled firms. Entrepreneurship theory and practice, 29(3), 249-265.

Chandler, A. D. (1990). Strategy and structure: Chapters in the history of the industrial enterprise (Vol. 120). MIT press.

Claessens, S., Djankov, S., Fan, J. P., \& Lang, L. H. (2002). Disentangling the incentive and entrenchment effects of large shareholdings. The journal of finance, 57(6), 2741-2771.

Coles, J. L., Lemmon, M. L., \& Meschke, J. F. (2012). Structural models and endogeneity in corporate finance: The link between managerial ownership and corporate performance. Journal of Financial Economics, 103(1), 149-168.

Cronqvist, H., \& Nilsson, M. (2003). Agency costs of controlling minority shareholders. Journal of Financial and Quantitative analysis, 38(4), 695-719.

Cucculelli, M., \& Micucci, G. (2008). Family succession and firm performance: Evidence from Italian family firms. Journal of Corporate Finance, 14(1), 17-31.

Daspit, J. J., Chrisman, J. J., Sharma, P., Pearson, A. W., \& Mahto, R. V. (2018). Governance as a source of family firm heterogeneity.

Dyer, W. G. (2018). Are family firms really better? Reexamining "examining the 'family effect'on firm performance". Family Business Review, 31(2), 240-248.

Demsetz, H., \& Lehn, K. (1985). The structure of corporate ownership: Causes and consequences. Journal of political economy, 93(6), 1155-1177.

Dlugosz, J., Fahlenbrach, R., Gompers, P., \& Metrick, A. (2006). Large blocks of stock: Prevalence, size, and measurement. Journal of Corporate Finance, 12(3), 594-618.

EY , Family Business Yearbook. (2017). Retrived from: https://familybusiness.ey-vx.com/fb-yearbookflipbook-2017/mobile/index.html\#p=1

Fabbrini, A., \& Micucci, G. (2004). Controllo familiare, struttura finanziaria e crescita delle imprese. Rivista di Politica Economica, 94(5), 167-202.

Gillan, S. L. (2006). Recent developments in corporate governance: An overview.

Gomez-Mejia, L. R., Larraza-Kintana, M., \& Makri, M. (2003). The determinants of executive compensation in family-controlled public corporations. Academy of management journal, 46(2), 226-237. La Porta, R., Lopez-de-Silanes, F., \& Shleifer, A. (1999). Corporate ownership around the world. The journal of finance, 54(2), 471-517. 
INTERNATIONAL JOURNAL OF ACADEMIC RESEARCH IN ACCOUNTING, FINANCE AND

MANAGEMENT SCIENCES

Vol. 11, No. 2, 2021, E-ISSN: 2225-8329 @ 2021 HRMARS

Greene, W. (2008). Econometric Analysis (6th ed.). Upper Saddle River: NJ: Prentice Hall.

Haizhu Zhang, Shengfeng Qin, Rong Li, Yisheng Zou, Guofu Ding. (2020) Progressive modelling of feature-centred product family development. International Journal of Production Research 58:12, pages 3701-3723.

Hausman, J. 1978, "Specification Tests in Econometrics." Econometrica, 46(6), pp. 1251-1271.

Holderness, C. G., \& Sheehan, D. P. (1988). The role of majority shareholders in publicly held corporations: An exploratory analysis. Journal of financial economics, 20, 317-346.

James, H. S. (1999). Owners as manager, extended horizonsandthefamilyfirm.InternationalJournalof the Economics of Business,6(1),41-55.

Jensen, M. C. (1986). Agency costs of free cash flow, corporate finance, and takeovers. The American economic review, 76(2), 323-329.

Jensen, M. C., \& Meckling, W. H. (1976). Theory of the firm: Managerial behavior, agency costs and ownership structure. Journal of financial economics, 3(4), 305-360.

La Porta, R., Lopez-de-Silanes, F., \& Shleifer, A. (1999). Corporate ownership around the world. The journal of finance, 54(2), 471-517.

Lotti, F., \& Santarelli, E. (2002). The survival of family firms: the importance of control and family ties (No. 461). Quaderni-Working Paper DSE.

Maury, B. (2006) Family ownership and firm performance:

EmpiricalevidencefromWesternEuropeancorporations,JournalofCorporate Finance, 12: 32144

Maury, B., \& Pajuste, A. (2005). Multiple large shareholders and firm value. Journal of Banking \& Finance, 29(7), 1813-1834.

McConaughy, D. L., Walker, M. C., Henderson Jr, G. V., \& Mishra, C. S. (1998). Founding family controlled firms: Efficiency and value. Review of Financial economics, 7(1), 1-19.

Melis, A. (1999) Corporate governance - Un'analisi empirica della realtà italiana in un'ottica europea. Torino: Giappichelli.

Melis, A. (2000) Corporate Governance in Italy, Corporate Governance: An International Review, 8 (4): 347-355.

Miller, D., Le Breton-Miller, I., \& Scholnick, B. (2008). Stewardship vs. stagnation: An empirical comparison of small family and non-family businesses. Journal of management studies, 45(1), 51-78.

Molteni, M. M. (1997). I sistemi di corporate governance nelle grandi imprese italiane. Egea.

Morck, R., Stangeland, D., \& Yeung, B. (2000). Inherited wealth, corporate control, and economic growth: the Canadian disease, in concentrated corporate ownership. In NBER Conference Volume. University of Chicago Press.

Pallant, J. (2010), SPSS Survival Manual: A Step by Step Guide to Data Analysis using SPSS, 4th ed., Open University Press, Berkshire.

Pérez-González, F. (2006). Inherited control and firm performance. American Economic Review, 96(5), 1559-1588.

Samara, G., \& Berbegal-Mirabent, J. (2018). Independent directors and family firm performance: does one size fit all?. International Entrepreneurship and Management Journal, 14(1), 149-172.

Saito, T. (2008). Family firms and firm performance: Evidence from Japan. Journal of the Japanese and International Economies, 22(4), 620-646. 
INTERNATIONAL JOURNAL OF ACADEMIC RESEARCH IN ACCOUNTING, FINANCE AND

MANAGEMENT SCIENCES

Vol. 11, No. 2, 2021, E-ISSN: 2225-8329 @ 2021 HRMARS

Schulze, W. S., Lubatkin, M. H., \& Dino, R. N. (2003). Exploring the agency consequences of ownership dispersion among the directors of private family firms. Academy of management journal, 46(2), 179-194.

Schulze, W. S., Lubatkin, M. H., Dino, R. N., \& Buchholtz, A. K. (2001). Agency relationships in family firms: Theory and evidence. Organization science, 12(2), 99-116.

Serino, L., Papa, A., Campanella, F., \& Di Gioia, L. (2020). The sourcing for collaborative knowledge translation in distributed $R \& D$ processes: a cross-regional study. Management Decision.

Stein, J. C. (1989). Efficient capital markets, inefficient firms: A model of myopic corporate behavior. The Quarterly Journal of Economics, 104(4), 655-669.

Stock, H. J., and Watson, M. W. (2012). Introduction to Econometrics, 3rd ed., Pearson AddisonWesley. Chapter 10.

Wu, T. C., \& Huang, M. (2018). The Effect of Director's Individual and Family Shareholdings on Firm Performance. International Journal of Financial Research, Vol. 9(4)

Van der Zee, D. J. (2013). Family based dispatching with batch availability. International Journal of Production Research, 51(12), 3643-3653.

Villalonga, B., \& Amit, R. (2006). How do family ownership, control and management affect firm value?. Journal of financial Economics, 80(2), 385-417.

Villalonga, B., \& Amit, R. (2006a). Benefits and costs of control-enhancing mechanisms in US family firms. ECGI WP Series in Finance, 209(247.216).

Xu, Q. L., Ong, S. K., \& Nee, A. Y. C. (2007). Evaluation of product performance in product family design re-use. International Journal of Production Research, 45(18-19), 4119-4141. 
INTERNATIONAL JOURNAL OF ACADEMIC RESEARCH IN ACCOUNTING, FINANCE AND MANAGEMENT SCIENCES

Vol. 11, No. 2, 2021, E-ISSN: 2225-8329 @ 2021 HRMARS

Table 1: Definition of family business the literature

\begin{tabular}{|l|l|}
\hline Author(s) & Definition used in research \\
\hline $\begin{array}{l}\text { Allen and Panian (1982); } \\
\text { Claessens et al. (2002) }\end{array}$ & $\begin{array}{l}\text { Family firm is a company in which the founding } \\
\text { family or its descendants own or control at least } \\
5 \text { percentage of the voting stock }\end{array}$ \\
\hline $\begin{array}{l}\text { Anderson and Reeb (2003) } \\
\text { Villalonga and Amit (2006) }\end{array}$ & $\begin{array}{l}\text { Family firms if the founder or a member of the } \\
\text { founding family is an officer, a director, or the } \\
\text { owner of at least 5\% of the firm's equity }\end{array}$ \\
\hline Ang, Cole, and Lin (2000) & $\begin{array}{l}\text { Family firm when the founding family held } \\
\text { more than 50\% of the firm's shares. }\end{array}$ \\
\hline Cronqvist and Nilsson (2003) & $\begin{array}{l}\text { Family firm whenever the founder or } \\
\text { descendents of the founder are present as } \\
\text { officers/directors }\end{array}$ \\
\hline $\begin{array}{l}\text { Dlugosz,Fahlenbrach, } \\
\text { Metrick(2006) }\end{array}$ & $\begin{array}{l}\text { Family firm whenever the founder is the senior } \\
\text { manager }\end{array}$ \\
\hline Holderness and Sheehan (1988) & $\begin{array}{l}\text { Family firm if the founding family or its } \\
\text { descendants own at least 50.1\% of the firm's } \\
\text { shares }\end{array}$ \\
\hline La Porta et al. (1999) & $\begin{array}{l}\text { Family firm if an individual is the controlling } \\
\text { shareholder whose voting rights exceed 20\%. }\end{array}$ \\
\hline
\end{tabular}

Source: Authors 'elaboration

Table 2: Characteristics of research sample

\begin{tabular}{|l|l|l|l|l|l|}
\hline \multicolumn{2}{|l|}{ Family firms } & $\begin{array}{l}\text { Non-family } \\
\text { firms }\end{array}$ & Total firms \\
\hline 185 & Family firms (M) & Family firms (O) & Sum & & 110 \\
\hline Family firms (M\&O) & 40 & 185 & & \\
\hline 74 & 71 & 405 & \\
\hline
\end{tabular}

Table 3: Fixed effects results

\begin{tabular}{|c|c|c|c|c|}
\hline$F(5.880)=21.12$ & p.valu & & & \\
\hline ROA & Coef. & Std. Err & $\mathrm{t}$ & $P>|t|$ \\
\hline Family & 1.487 & 0.647 & 2.30 & $0.022 *$ \\
\hline Ownership & 0.028 & 0.008 & 3.56 & $0.000 *$ \\
\hline$M$ family firm & 0.685 & 0.848 & 0.81 & 0.420 \\
\hline $\begin{array}{l}O \text { family firm } \\
M \& O \quad \text { family }\end{array}$ & 2.564 & 0.562 & 4.56 & $0.000^{*}$ \\
\hline firm & 0.147 & 0.519 & 0.28 & 0.776 \\
\hline cons & 4.065 & 0.416 & 9.77 & $0.000 *$ \\
\hline
\end{tabular}

$\mathrm{F}$ test that all $\mathrm{u}_{-} \mathrm{i}=0, \mathrm{~F}(294.880)=3.40 \quad$ Prob $>\mathrm{F}=0.000 ;{ }^{*}$ significant at $5 \%$ 
INTERNATIONAL JOURNAL OF ACADEMIC RESEARCH IN ACCOUNTING, FINANCE AND MANAGEMENT SCIENCES

Vol. 11, No. 2, 2021, E-ISSN: 2225-8329 @ 2021 HRMARS

Table 4: GLS Random Effects results

\begin{tabular}{lllll}
\hline \multicolumn{6}{l}{ Wald chi2(5) } & $\mathbf{1 4 5 . 4 4}$ p.value $=\mathbf{0 . 0 0 0 0}$ & & \\
\hline ROA & Coef. & Std. Err & $\mathrm{z}$ & $\mathrm{P}>|\mathrm{z}|$ \\
\hline Family & 1.787 & 0.594 & 3.010 & $0.003^{*}$ \\
Ownership & 0.026 & 0.008 & 3.460 & $0.001^{*}$ \\
M family firm & -0.525 & 0.522 & -1.000 & 0.315 \\
O family firm & 2.498 & 0.514 & 4.860 & $0.000^{*}$ \\
M\&O family & & & & \\
firm & 0.915 & 0.473 & 1.940 & $0.053^{*}$ \\
cons & 4.151 & 0.411 & 10.090 & $0.000^{*}$ \\
\hline
\end{tabular}

*significant at $5 \%$ 